\title{
THE ROLE OF PROSODIC MEANS IN REALIZING THE PRAGMATIC EFFECT
}

\author{
L. S. KOZUB, PhD in Philology, Associate Professor, \\ National University of Life and Environmental Sciences of Ukraine \\ E-mail: liubatern@yahoo.com \\ ORCID: 0000-0002-6617-6442
}

\begin{abstract}
The article deals with the pragmatics of an oral informational text and its correlation with intonation. Special attention is paid to the theory of intonation. The work highlights the importance of an illocutionary act by which the definite communicative intention is meant and studies the illocutionary function of intonation, which is the marker of the illocutionary act.

The pragmatic function of intonation is viewed as one of the main functions of the linguistic system. The intonational division of the text into syntagms is one of the main ways of expressing the pragmatic function of intonation in oral texts. It does not only create discretion that is necessary for understanding of the text content, but also integrates the segmented units that form the content of the text as a whole. The obtained results may contribute to further study of the prosodic organization of oral informational texts, particularly $T V$ commercials, their influence on the addressee and peculiarities of their perception.
\end{abstract}

Keywords: prosodic means, pragmatic features, pragmatic function of intonation, addressee, informational text, linguistic system

Introduction. Analysis of phonetic phenomena through the prism of pragmatic problems meets the requirements that science puts today to linguistic research. A pragmatic approach to the study of phonetic phenomena proved the necessity to turn to such disciplines as: psychology, sociology, philosophy, etc. Accordingly, it is obvious that an integrated approach to the study of the text as a systemic phenomenon is inevitable. Considering the theory of intonation, it becomes clear that the pragmatic function of intonation can be regarded as one of the main functions of the linguistic system. However, it should be taken into consideration that in specific types of text, this function is considered in accordance with their pragmatic peculiarities.

Analysis of recent researches and publications. Modern world is saturated with information systems that contain a large amount of information and which doubles that amount every ten to fifteen years. An important role in this process is played by the study of oral informational texts, in particular advertising, for the purpose of their optimal structuring and perception, which are provided by the pragmatic potential of these texts. The study of informational texts was in the focus of increased interest of many researchers: K. Boost, M. A. K. Halliday, N. I. Serov, F. Danesh, T. P. Ivanov, L. A. Chernyakhovska, and others.

Contemporary pragmatics is a large, active, interdisciplinary field that studies the relationship between signs and people who create, transmit and accept language signs. Accordingly, it can be argued that a number of issues pragmatics is concerned with are relevant to advertising, in particular, the impact of the text on the addressee, increasing the awareness of the addressee, changing his/her emotional state, views and assessments, the impact on his/her actions, etc. Thus, the pragmatic peculiarities of any advertising are presupposed by the necessity to

(C) L. S. Kozub

«International journal of philology» | «Міжнародний філологічний часопис» Vol. 10, № 2, 2019 
encourage the addressee to take appropriate actions, purchase, use some service or change an opinion about the advertising item.

The purpose of the research is to study the role of prosodic means in realizing the pragmatic effect of oral informational texts.

The methods of investigation are the following: the studying and critical analysis of the literature on the problem, methods of deduction and synthesis.

Results. In modern linguistics the field that emerged not so long ago and is called pragmalinguistics explores the connections between the language and those who use it. At the same time, there's firmly established tradition to consider the pragmatics of the verbal sign in connection with the function of emotional influence, which is provided by emotionallyexpressive linguistic means [10, p. 87]. According to this theory, only those functional styles and texts that are represented by emotionally-expressive means can be considered pragmatic, and styles whose main features are information function and the absence of emotionally-expressive means do not relate to pragmatically relevant ones.

According to $\mathrm{G}$. Klaus, information in general and the message in particular affect the person who receives the message and modify his/her behavior [5, p. 26]. The difference between these linguistic means is that they modify various, albeit interrelated, types of human behavior - sensory and intellectual. It is believed that intellectual behavior manifests itself in the ability to effectively process information, in the execution of various operations of logical thinking. Proceeding from the study of intellectual behavior from a psychological perspective, the pragmatics of the informational text can be defined as a specific control of the perception of information contained in this text, aimed at modifying the behavior of the recipient.
Consequently, the views of linguists differed on the influence of texts: from the recognition of all texts influential to admitting that pragmatically oriented are specially composed texts. Thus, I. P. Susov states that, regardless of whether the text is narrative, interrogative or imperative, its ultimate goal is to provide influence [11, p. 8]. Of course, any text presupposes a deliberate intention of the author to influence the recipient in some way, and in this sense every text has a pragmatic orientation, but, on the other hand, it is necessary to take into account the degree, the intensity of this pragmatic orientation, the quantity and quality of influential linguistic means, the aim of pragmatic means usage (to influence recipients' mind, will, emotions, etc.), the degree of their influence and the final result.

The purpose of most messages, especially informational, is to influence or control the behavior of the recipient of information. Accordingly, the pragmatics of the text deals with the study of the regulatory influential part of the message. In the opinion of the German linguist $\mathrm{V}$. Dressler, the question of the purpose and intention of the sender of information is actually pragmatic. At the same time, he draws attention to the following functions: informative function - informing the addressee using texts; imperative function - call for evaluation or certain behavior; evaluative function assessment of the sender of information; addressing function [8, p. 14]. Moreover, it is assumed that all these functions are subordinated to a single goal - to influence the recipient and can be interpreted as different ways of producing the influence - direct influence (stimulation function) and indirect influence (informative function, addressing function, evaluative function).

It's important to note that rather complicated question while considering text pragmatics is the role of the sender's

(c) L. S. Kozub

«International journal of philology» | «Міжнародний філологічний часопис» Vol. 10, № 2, 2019 
intention and the intention of the recipient of the text. The intention of the sender depends on the selection of sentences, their combination, and prosodic organization. Considering this G. Matveyeva draws attention to the fact that the sender of information should take into account the intention of the recipient of this information, that is to expect a certain coherence in the text [8, p. 15]. In this aspect, the important role is played by the beginning of the text: it creates a specific expectation in the addressee and outlines the pragmatic framework of the text.

The results of the study by V. L. Nayer $[10$, p. 107] allow us to state that pragmatic tasks of the sender of the oral informational text are universal. It is first of all the influence on the addressee, where an important role plays prosody. To address the problem of impact, the sender knowingly or unconsciously chooses a strategy when creating the text. This activity involves the implementation of certain general pragmatic plans of influence on the addressee. This is primarily a plan of direct and indirect influence. It should be remembered that when we talk about the pragmatic peculiarities of the text, we mean the effect of a rather high degree of intensity, the presence of both intellectual and emotional evaluation means.

Considering the research of $A$. $L$. Belyakov [3, p. 97], we can conclude that when describing the pragmatics of the oral informational text, three aspects can be distinguished: 1) the pragmatic intention of the sender, 2) the pragmatic "orientation" of the text, and 3) the pragmatic intention of the recipient. The main role in this case plays the pragmatic intention of the sender, which when creating the text poses a certain task. According to it, the informational text acquires pragmatic orientation in accordance with the task and thus influences the recipient. The transmission of any informational message can be represented on the scheme: Sender - Text - Recipient.

An overview of theoretical and experimental studies of various linguistic aspects proved that modern linguistics is increasingly concerned with a comprehensive and in-depth analysis of oral speech, its features, means of expressiveness, effectiveness, in the realization of which a significant role play prosodic means $[4$, p. $476 ; 6$, p. $75 ; 10$, p. 126; 12, p. 43]. Many linguists in their studies consider the role of prosodic means in realizing the pragmatic effect. For example, L. Kisilova views prosodic means only as amplifiers of the pragmatic meaning. However, the question of the role of prosodic means as amplifiers, that is, means that are only subordinate, is controversial. Some linguists point out that in oral speech, the question of what is more important intonation or lexicalsyntactic structure is debatable, but with regard to oral informational texts, it can be argued that one of the main structures is the sound-intonational structure. According to J. Fora, in some types of oral speech words and the syntactic organization are only a "theme", and communicative content is expressed mainly by the prosody [2, p. 52].

Linguistic studies suggest that an illocutionary act, which is considered as a synonym of communicative intention, is of paramount importance in pragmatics. Responsively, the linguistic action is a set of speech acts, where the illocutionary act is the dominant one. In the works on pragmatics linguists consider the illocutionary function of intonation, because intonation is a marker of the illocutionary act. Pragmatic function of intonation was considered by N. I. Zhynkin, A. Kalyta, C. KerbratOrecchioni, I. R. Galperin, F. Recanati, and others.

It should also be noted that in the structure of the text intonation peculiarities reflect changes of illocutionary microacts,

(C) L. S. Kozub

«International journal of philology» | «Міжнародний філологічний часопис» Vol. 10, № 2, 2019 
the sequence of which constitutes the illocutionary macroact. Judging from this, the intonational structure of the text is a system of illocutionary functions of intonation. This system is compiled under the influence of extratextual and intertextual relationships that characterize each text as a systemic entity. As it has been mentioned above, it is a system of interacting, rather than isolated relationships, because there is a factor that defines the features of these types of relationships. With regard to informational, in particular advertising texts, influence is considered to be this factor. So, in relation to all informational texts we can speak about the influential (pragmatic) function of intonation. But for the allocation of the pragmatic function of intonation, it is not enough to indicate the role of intonation to create the influence effect. It is important to show the value of intonation in the content structure of the text. Integration of text units containing illocutionary microacts leads to the formation of text content and is carried out by means of intonation [7, p. 56].

In the opinion of J. Austin, the founder of speech act theory, an utterance intended to affect the listener has a perlocutionary aspect [1]. It is therefore obvious that each advertising text has a certain perlocutionary effect. Thus, a successful prosodic organization of the advertising text provides a successful illocutionary act realization and the creation of a certain perlocutionary effect due to the intention of the author.

In addition, it is believed that in determining the overall content of the utterance the following factors are involved: the system of verbal and nonverbal means, that is lexical, syntactic, prosodic features as well as body language; some elements of the situation of utterance; linguistic and paralinguistic competence of the recipients, which creates a system of knowledge, ideas and assessments of the surrounding world [7, p. 55].

\section{Conclusions and research} prospects. Thus, we can conclude that illocutionary acts, which determine the speaker's intentions, are of primary importance in pragmatics. Equally important is understanding the textformation mechanism, that is the process of illocutionary macroacts actualization, as well as the perlocutionary aspect realization in oral informational texts. Regarding the pragmatic function of intonation, it is viewed as one of the main functions of the linguistic system. The intonational division of the text into syntagms is one of the main ways of expressing the pragmatic function of intonation in oral texts. It does not only create discretion that is necessary for understanding of the text content, but also integrates the segmented units that form the content of the text as a whole. From the adequate nature of the text intonation depends on the understanding of the text by listeners, their psychological reaction.

The obtained results may contribute to further study of the prosodic organization of oral informational texts, particularly TV commercials, their influence on the addressee and peculiarities of their perception.

\section{Список використаних джерел}

1. Остин Дж. Л. Слово как действие Новое в зарубежной лингвистике. Москва: Прогресс, 1986. Вып. 17: Теория речевых актов. С. 22-129.

2. Беличенко, Л. Г. Прагматическая функция просодии в некоторых видах реализации информационно-

публицистического

текста.Просодические

средства организации стилистически различных текстов в современном английском языке: Межвуз. сб. науч. тр. Москва : Изд-во МГПИ, 1990. С. 43-63.

3. Беляков А. А. Прагматические
характеристики интроспективных
сегментов. Прагматические аспекты

(C) L. S. Kozub

«International journal of philology» | «Міжнародний філологічний часопис» Vol. 10, № 2, 2019 
изучения предложения и текста : Сб. науч. тр. Киев: Изд-во КГПИИЯ, 1983. C. 95-101.

4. Калита А. А. Критерий уровня актуализации прагматического эмоциональнопотенциала записки высказывания.Наукові Кіровоградського педагогічного державного університету ім. В. Винниченка. Вип. 105 (1). Серія: Філологічні науки (мовознавство): У 2 ч. Кіровоград: РВВ КДПУ ім. В. Винниченка, 2012. С. 476-484.

5. Клаус Г. Сила слова. Москва. : URSS, 2018. $216 \mathrm{c}$.

6. Козуб Л. С. Роль просодії для реалізації впливу на адресата. Сучасні дослідження 3 іноземної фрілології: збірник наукових праць / Ужгородський національний університет. Вип. 13. Ужгород: ПП «Аутдор-Шарк», 2015. С. 74-79.

7. Ленца Д. Л., Соловьёва Е. В. Фонетика в аспекте прагматики. Кишинёв: Штиинца, 1989. 94 с.

8. Матвеева Г. Г. Актуализация прагматического аспекта научного текста. Ростов: Изд-во Ростовск. ун-та, 1984. $132 \mathrm{c}$.

9. Найдов Б. П. К проблеме прагматики научно-технического текста. Прагматические аспекты изучения предложения и текста : Сб. науч. тр. Киев: Изд-во КГПИИЯ, 1983. C. 87-92.

10. Наер, В. Л. Прагматический аспект английского газетного текста. Коммуникативные и прагматические особенности текстов разных жанров: Сб. науч. тр. Москва: Изд-во МГПИИЯ им. Мориса

Тореза,

1981. Вып. 178. С. 106-116.

11. Сусов, И. П. Семантика и прагматика предложения. Калинин : Калинин. гос. ун-т, 1990. 50 с.

12. Taranenko, L. I. The Role of Prosodic Means in Decoding the Riddle Answer. Сучасні тенденції фонетичних досліджень: зб. матеріалів Круглого столу. Куіv: КПІ ім. Ігоря Сікорського, 2018. C. 42-44.

\section{References}

1. Austin, J. L. (1986). Slovo kak deystvie [How to Do Things with Words]. Novoe $v$ zarubezhnoy lingvistike [New in Foreign Linguistics. XVII Speech acts theory]. Moscow, Progress, 22-129 [in Russian].

2. Belichenko, L. G. (1990). Pragmaticheskaya funktsiya prosodii $\mathrm{V}$ nekotoryih vidah realizatsii informatsionno-publitsisticheskogo teksta [Pragmatic function of prosody in some types of the informational and publicistic text realization]. Prosodicheskie sredstva organizatsii stilisticheski razlichnyih tekstov $\mathrm{v}$ sovremennom angliyskom yazyike [Prosodic means of organizing stylistically different texts in contemporary English]. Moscow, MSPI, 43-63 [in Russian].

3. Belyakov, A. A. (1983). Pragmaticheskie harakteristiki introspektivnyih segmentov [Pragmatic Characteristics of Introspective Segments]. Pragmaticheskie aspektyi izucheniya predlozheniya i teksta [Pragmatic aspects of the study of the sentence and the text]. Kiev, 95-101 [in Russian].

4. Kalita, A. A. \& Taranenko, L. I. (2012). Kriteriy urovnya aktualizatsii emotsionalno-pragmaticheskogo

potentsiala vyiskazyivaniya [The criterion of actualization level of an utterance's emotional and pragmatic potential]. Naukovi zapiski. Serija: Filologichni nauki (movoznavstvo) [Proceedings of Kirovograd State Pedagogical University named after. V. Vynnychenko. Series: Philological Sciences (linguistics)], 105 (1), 476-484 [in Russian].

5. Klaus, G. (2018). Sila slova [The Power of Words]. Moscow, URSS, 216 [in Russian].

6. Kozub, L. S. (2015). Rol prosodii dlia realizatsii vplyvu na adresata [The Role of Prosody in Realizing the Influence 
on the Addressee]. Suchasni doslidzhennia $z$ inozemnoi filolohii [Modern studies in foreign philology]. Uzhhorod, Autor-Shark, 74-79 [in Ukrainian].

7. Lentsa, D. L. \& Soloviova, Ye. V. (1989). Fonetika $\mathrm{v}$ aspekte pragmatiki [Phonetics in the Aspect of Pragmatics]. Chisinau, Shtiintsa, 94 [in Russian].

8. Matveeva, G. G. (1984). Aktualizatsiya pragmaticheskogo aspekta nauchnogo teksta [Actualization of the Pragmatic Aspect of the Scientific Text]. Rostov, 132 [in Russian].

9. Naidov, B. P. (1983). K probleme pragmatiki nauchno-tehnicheskogo teksta [On the Problem of Pragmatics of the Scientific and Technical Text]. Pragmaticheskie aspektyi izucheniya predlozheniya i teksta [Pragmatic aspects of the study of the sentence and the text]. Kiev, 87-92 [in Russian].

10. Nayer, V. L. (1981). Pragmaticheskiy aspekt angliyskogo gazetnogo teksta [Pragmatic Aspect of the English Newspaper]. Kommunikativnyie i pragmaticheskie osobennosti tekstov raznyih zhanrov [Communicative and pragmatic features of texts of different genres]. Moscow, 178, 106-116 [in Russian].

11. Susov, I. P. (1990). Semantika i pragmatika predlozheniya [Semantics and Pragmatics of the Sentence]. Kalinin, $\mathrm{KSU}, 50$ [in Russian].

12. Taranenko, L. I. (2018). The Role of Prosodic Means in Decoding the Riddle Answer. Suchasni tendentsii fonetychnykh doslidzhen [Modern trends in phonetic research]. Kyiv, KPI, $42-44$ [in Ukrainian].

\section{РОЛЬ ПРОСОДИЧНИХ ЗАСОБІВ У РЕАЛІЗАЦІЇ ПРАГМАТИЧНОГО ЕФЕКТУ}

\section{Л. С. Козуб}

Анотація. Аналіз фонетичних явищ крізь призму проблем прагматики відповідає тим вимогам, які наука ставить сьогодні до лінгвістичних досліджень. Прагматичний підхід до дослідження фоонетичних явищ зробив неминучим звернення до низки дисциплін, таких як: психологія, соціологія, фрілософрія тощо. Виходячи з цього, очевидним $\epsilon$ неминучість комплексного підходу у вивченні тексту як системного явища, всі елементи якого знаходяться у тісній взаємодії. 3 точки зору теорії інтонації прагматична фрункція інтонації може розглядатися як одна 3 головних функцій лінгвістичної системи. В конкретних типах тексту ия фуункція розглядається відповідно до їх прагматичних особливостей. Одним з головних способів вираження прагматичної функції інтонації в усних текстах є інтонаційне членування тексту на синтагми і висловлювання, що не лише створює необхідну для розуміння змісту дискретність, але і здійснює інтеграцію виділених одиниць, які утворюють зміст всього тексту в цілому. Від адекватної характеру тексту інтонації залежить розуміння тексту слухачами, їх психологічна реакція.

Ключові слова: просодичні засоби, прагматичні особливості, прагматична фрункція інтонації, адресат, інфрормаційний текст, лінгвістична система 